\title{
CORRIGENDUM
}

\section{Clinical utility gene card for: Glanzmann thrombasthenia}

Mathieu Fiore, Alan T Nurden, Paquita Nurden and Uri Seligsohn

European Journal of Human Genetics (2012) 20, 1102; doi:10.1038/ejhg.2012.178

Correction to: European Journal of Human Genetics (2012) 20, 1101; doi:10.1038/ejhg.2012.151; published online 11 July 2012

Since the publication of this article, the authors have noticed that Uri Seligsohn's name was incorrectly spelt. This has now been rectified and the corrected article appears in this issue. The html and online versions have also been rectified.

The authors would like to apologise for this error. 